\title{
Impact of Long-Term Application of Domestic Sewage Water on Soil Properties Around Hubli City in Karnataka, India
}

\author{
Bincy K. Varkey ${ }^{1}$ G. S. Dasog ${ }^{1} \cdot$ Suhas $_{W^{2} i^{2}} \cdot$ K. L. Sahrawat ${ }^{2}$. \\ Manjunatha Hebbara $^{1}$ C. R. Patil ${ }^{1}$
}

Received: 29 September 2014/ Accepted: 5 June 2015

(C) NAAS (National Academy of Agricultural Sciences) 2015

\begin{abstract}
The effects of application of domestic sewage water for over four decades on physical, chemical and biological properties of soils were studied at three sites in Gabbur, Mavanur and Katnur villages near Hubli city in North Karnataka, India. Long-term use of sewage irrigation improved soil physical properties in terms of decrease in bulk density and dispersion index and increase in aggregate stability and water holding capacity compared to the unirrigated check. Despite long-term irrigation with sewage water with an EC of $>1 \mathrm{dS} \mathrm{m}^{-1}$, the EC of soils was low $\left(0.20-0.45 \mathrm{dS} \mathrm{m}^{-1}\right)$. An increase of one-and-half to two times in organic carbon content, available N, P, K and S, in the sewage irrigated soils was observed compared to soils not irrigated with sewage. However, the available $\mathrm{Zn}, \mathrm{Fe}, \mathrm{Cu}$ and $\mathrm{B}$ increased only slightly with the exception of Mn which increased substantially. In general there was a decreasing trend of organic carbon, available $\mathrm{N}$, $\mathrm{P}, \mathrm{K}$ and $\mathrm{S}$ with distance away from the stream course. Despite no heavy metals in sewage water, they were detected in soils but not in toxic levels. There were 94, 80 and $60 \%$ more bacteria, fungi and actinomycetes, respectively, in sewage irrigated soils over the non-irrigated soils. Further, the coliform bacteria (E. coli) were observed in soil samples, suggesting fecal contamination.
\end{abstract}

Keywords Heavy metals - Microbial count $\cdot$ Nutrient status $\cdot$ Sewage water $\cdot$ Soil properties $\cdot$ Water quality

\section{Introduction}

Water is a vital but a severely limited resource in most developing countries. The average availability of water is reducing steadily with the growing population, and it is estimated that by 2020 India will become a water-stressed nation. Hence, the use of wastewater has been a common practice, especially in the peri-urban areas [14] to meet the challenges of scarce water resource in terms of sustainability, food and income security and environmental safety.

G. S. Dasog

dasoggs@uasd.in

1 University of Agricultural Sciences, Dharwad, Karnataka, India

2 International Crops Research Institute for Semi-Arid Tropics, Patancheru, Hyderabad, India
An estimated 38,354 million litres per day of sewage water is generated in major cities of India [4]. The sewage water is a potential water resource with stability of water quantity and reliable supply. Nutrients and water being the most critical inputs in agriculture, harvesting the nutrients and irrigation potential of sewage water are of prime importance for maximizing the food, fodder and fuel production. Sewage water is a rich source of both beneficial and harmful elements. Many small to medium scale industries operating in peri-urban residential areas of cities dispose their contaminated effluents directly in sewage system. Disposal of waste water on agricultural soils in the longer-term could potentially adversely affect soil health. The implications associated with heavy metal contamination are of great significance, particularly in agricultural production systems. Although a number of studies on impact of sewage water irrigation on soils and plants is made [15, 17], most of them are confined to north Indian alluvial plains. Very few in-depth studies are done [16] on 
clayey soils of southern India in a transitional zone (neither heavy nor low rainfall).

About 60 million litres of waste water is being generated every day in Hubli-Dharwad twin cities, which is being utilized by the farmers for growing various crops during dry seasons. This practice is in vogue for four decades as per socioeconomic survey conducted in the villages. This study, was conducted with an objective to study the changes in soil physical, chemical and biological properties at distances away from the course as well as with depth as affected by sewage irrigation for over 40 years as compared to a control (without sewage irrigation) treatment.

\section{Materials and Methods}

\section{Study Sites}

The Hubli-Dharwad Municipal Corporation is the second largest in Karnataka State. The Hubli city is located in a predominantly rural region where agriculture is the principal activity due to the productive nature of the soils. The investigation was carried out in three villages located along the stream course (Fig. 1). These three villages lie between $15^{\circ} 16^{\prime} 51.24^{\prime \prime}$ and $15^{\circ} 07^{\prime} 00.17^{\prime \prime} \mathrm{N}$ latitudes around $75^{\circ} 07^{\prime} 00.17^{\prime \prime} \mathrm{E}$ longitude at an altitude of $595 \mathrm{~m}$ above the MSL. Whereas the crops grown include vegetables, cotton, maize, sugarcane, pulses etc. in rabi (post-rainy season) and summer season for more than four decades in Gabbur. The small holder farmers reserve their entire land for intensive vegetable cultivation as it sustains their economy. Fruit and plantation crops occupied major area in Mavanur and Katnur. The climate of Hubli region is semi-arid with an average annual rainfall of $711 \mathrm{~mm}$ with biennial distribution with two peaks one in July and another in October. The sewage water irrigation is given during late rabi and summer season crops after rains recede.

The sewage water samples were collected from three villages Gabbur, Mavanur, Katnur which are located at 2, 3 and $6 \mathrm{~km}$, respectively, from outer boundary of Hubli city, along the sewage stream. The composition of the sewage water is enumerated in Table 1 . The $\mathrm{Ca}$ and $\mathrm{Mg}$ concentration offsets the bicarbonates thus resulting in RSC values less than 2.5. The sewage waters can be grouped as of good quality irrigation water as per the classification by [13].

\section{Soil Sampling and Analysis}

In each village, soil samples were collected from three depths $(0-20,20-40,40-60 \mathrm{~cm})$ at a distance of 50, 150, $250 \mathrm{~m}$, perpendicular to the course of the stream. The soil samples were also collected from the farmers' fields which have not been irrigated with sewage water. For assessing

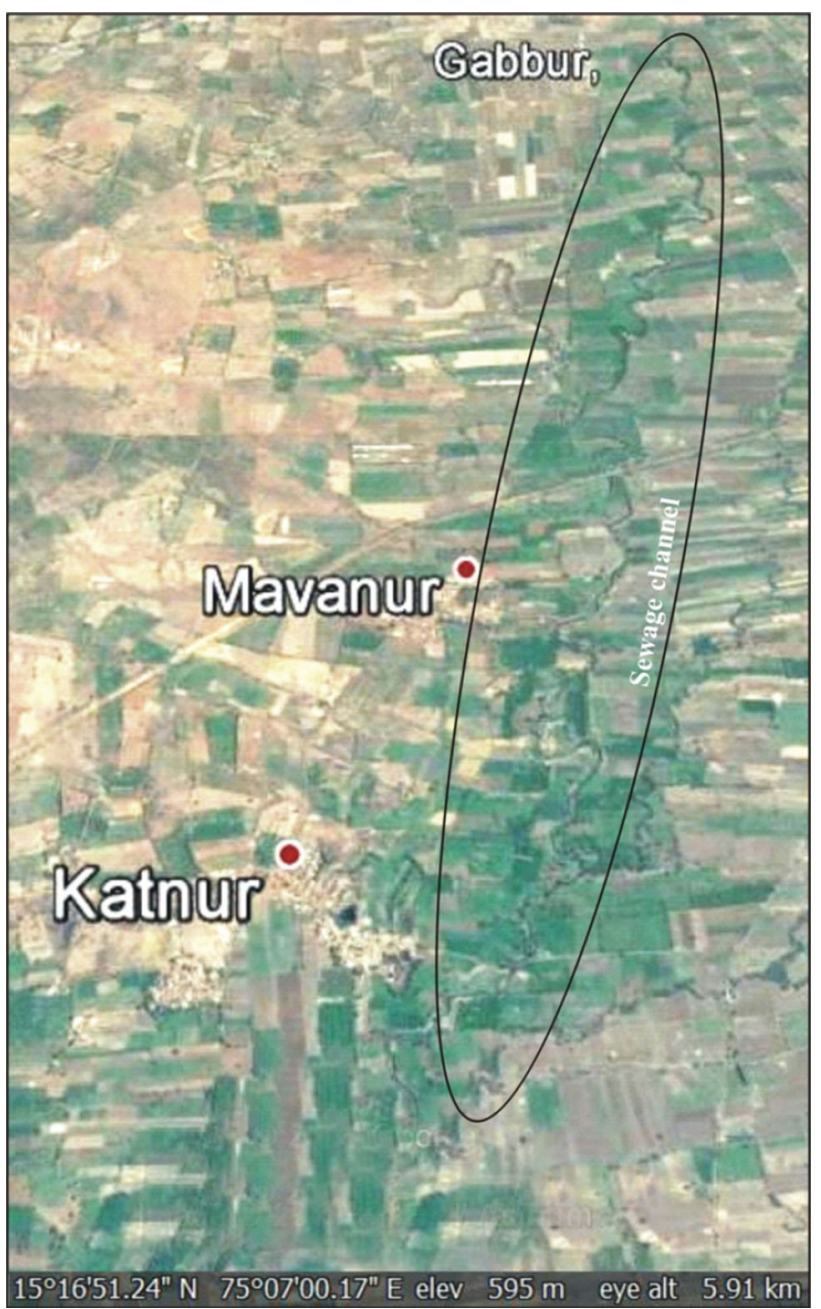

Fig. 1 Sewage water sampling sites

Table 1 Characteristics of sewage water used for irrigation from the sites

\begin{tabular}{|c|c|c|c|}
\hline Parameter & Gabbur & Mavanur & Katnur \\
\hline $\mathrm{pH}$ & 6.79 & 7.47 & 7.40 \\
\hline $\mathrm{EC}\left(\mathrm{dS} \mathrm{m} \mathrm{m}^{-1}\right)$ & 1.14 & 1.26 & 1.23 \\
\hline Chloride (me $\mathrm{L}^{-1}$ ) & 7.3 & 7.8 & 8.0 \\
\hline Sulphate $\left(\mathrm{mg} \mathrm{L}^{-1}\right)$ & 6.6 & 7.5 & 7.2 \\
\hline Bicarbonate $\left(\right.$ me L $^{-1}$ ) & 7.7 & 8.2 & 7.8 \\
\hline Total N (mg L $\left.{ }^{-1}\right)$ & 19.9 & 20.3 & 19.7 \\
\hline Phosphate $\left(\mathrm{mg} \mathrm{L}^{-1}\right)$ & 16.1 & 17.4 & 16.7 \\
\hline Potassium (me L ${ }^{-1}$ ) & 0.76 & 0.80 & 0.74 \\
\hline Sodium $\left(\mathrm{me} \mathrm{L}^{-1}\right)$ & 5.4 & 6.2 & 5.9 \\
\hline $\mathrm{Ca}+\mathrm{Mg}\left(\mathrm{me} \mathrm{L}^{-1}\right)$ & 6.5 & 7.6 & 6.6 \\
\hline $\mathrm{Zn}\left(\mathrm{mg} \mathrm{L}^{-1}\right)$ & 0.05 & 0.05 & 0.06 \\
\hline $\mathrm{Fe}\left(\mathrm{mg} \mathrm{L}^{-1}\right)$ & 0.07 & 0.06 & 0.07 \\
\hline $\operatorname{Mn}\left(\mathrm{mg} \mathrm{L}^{-1}\right)$ & 0.13 & 0.07 & 0.15 \\
\hline $\mathrm{Cu}\left(\mathrm{mg} \mathrm{L}^{-1}\right)$ & 0.05 & 0.04 & 0.05 \\
\hline
\end{tabular}


the microbial count in the sewage irrigated profiles fresh soil samples were taken from the rhizosphere region of crops from the three village sites.

The soil properties were determined by adopting standard procedures. Maximum water holding capacity (MWHC) was determined using Keen's cup. Bulk density was determined by core method. Water stable soil aggregates were determined by wet sieving method [10]. Dispersion index was determined as described by [7]. The available sulphur and boron in the soil samples were determined by hot water extraction method [3]. The other measurements were carried out following standard procedures [9]. The microbial load in the rhizosphere soil sampled from the sites irrigated with and without sewage water was also enumerated. The isolation and enumeration of bacteria, fungi, actinomycetes and E. coli was done using serial dilution and standard plate count technique [2].

\section{Results and Discussion}

\section{Physical Properties of Soils}

The soils of all the three village sites used belonged to clay texture (data not shown). The bulk density of the soils irrigated with sewage water was lower as compared to that of the unirrigated control samples (Table 2). The lower bulk density and improvement in percent porosity in sewage irrigated soils is due to the addition of organic matter in the surface layers $[11,16,17]$. Sewage water irrigated profile samples had higher MWHC and lesser dispersion index and higher aggregate stability compared to soils not irrigated with sewage water (Table 2) again due to the addition of organic matter by sewage irrigation which plays an important role in improving the soil physical environment. The effect of organic matter addition through sewage water on aggregation improves soil structure and enhances water transmission [12].

\section{Chemical Properties of Soils}

The soils irrigated with sewage water exhibit a $\mathrm{pH}$ of one to half unit higher than the $\mathrm{pH}$ of sewage water (Table 3). Soils exhibited EC of $0.20-0.45 \mathrm{dS} \mathrm{m}^{-1}$ despite irrigated with sewage water with $\mathrm{EC}>1.0 \mathrm{dS} \mathrm{m}^{-1}$ suggesting good soil drainage. Relatively higher content of organic carbon in sewage irrigated profiles was registered due to addition of organic matter (high BOD of 283-375 in sewage water) through longterm application of sewage. These results are in agreement with those reported by [5] and [17]. Thus, sewage application to soils is considered a carbon building and soil quality sustaining practice. The cation exchange capacity of the soils was comparatively higher in soils irrigated with sewage water possibly due to accumulated stable carbon compounds as organic colloids that consequently improved CEC.

\section{Available Nutrient Status of Soils}

The content of available N, P, K and S status of soils irrigated with sewage water was higher by one and a half to two times compared to the check. Soils of Gabbur site, which was located nearer to the sewage outlet, exhibited higher levels than the other two due to its vicinity to the sewage outlet than the other two (Table 3). [1, 8], also reported enhancement of available nutrient status of soils irrigated with sewage water. In terms of their status, however, available $\mathrm{N}$ remained low in all the sites, and available $\mathrm{K}$ marginally high in Gabbur and Mavanur sites with a medium status in Katnur site. The levels of available $\mathrm{P}$ stood out in all soils by its high status, especially in Gabbur and Mavanur sites. This is a reflection of high $\mathrm{P}$ status in the sewage water due to contamination from detergents used in the households.

In general there was a decrease in levels of organic carbon, in Gabbur and Katnur sites, going from 50 to $250 \mathrm{~m}$ away from stream course, while it was highest at $150 \mathrm{~m}$ in Mavanur showing a slight decrease at 50 and $250 \mathrm{~m}$. With respect to available $\mathrm{P}$ and $\mathrm{K}$ there was a decrease with distance with the exception of Mavanur showing higher value at $250 \mathrm{~m}$ than $150 \mathrm{~m}$. Ca, $\mathrm{Mg}$ and boron did not exhibit any trend as observed for other nutrients. [17] also observed a decrease in nutrient levels moving away from outlet as well as away from the stream course, although they observed the effect of sewage up to $1 \mathrm{~km}$ off the stream course.

Table 2 Physical properties of soils irrigated with sewage water (averaged over depth and distance away from stream)

\begin{tabular}{lcccc}
\hline Physical property & Gabbur & Mavanur & Katnur & Not irrigated with sewage \\
\hline Bulk density $\left(\mathrm{Mg} \mathrm{m}^{-3}\right)$ & 1.36 & 1.41 & 1.31 & 1.55 \\
Porosity (\%) & 48.3 & 46.8 & 50.3 & 41.4 \\
MWHC (\%) & 61.8 & 61.8 & 73.1 & 54.8 \\
Dispersion index (\%) & 9.0 & 8.5 & 11.1 & 14.7 \\
Aggregate stability (\%) & 56.2 & 61.5 & 62.2 & 52.0 \\
\hline
\end{tabular}


Table 3 Distribution of chemical properties of soils irrigated with sewage with distance from the stream (average of three depths)

\begin{tabular}{|c|c|c|c|c|c|c|c|c|c|c|}
\hline \multirow[t]{3}{*}{ Soil parameters } & \multicolumn{9}{|c|}{ Distance from the stream $(\mathrm{m})$} & \multirow{3}{*}{$\begin{array}{l}\text { Sewage } \\
\text { unirrigated }\end{array}$} \\
\hline & \multicolumn{3}{|c|}{ Gabbur } & \multicolumn{3}{|c|}{ Mavanur } & \multicolumn{3}{|c|}{ Katnur } & \\
\hline & 50 & 150 & 250 & 50 & 150 & 250 & 50 & 150 & 250 & \\
\hline $\mathrm{pH}(1: 2.5)$ & 7.90 & 7.99 & 7.98 & 7.83 & 7.48 & 7.80 & 8.54 & 8.67 & 8.51 & 8.05 \\
\hline $\operatorname{EC}(1: 2.5)\left(\mathrm{dS} \mathrm{m}^{-1}\right)$ & 0.39 & 0.33 & 0.32 & 0.28 & 0.20 & 0.29 & 0.45 & 0.42 & 0.41 & 0.58 \\
\hline O.C $\left(\mathrm{g} \mathrm{kg}^{-1}\right)$ & 4.9 & 6.2 & 3.4 & 8.7 & 11.5 & 9.0 & 9.1 & 8.5 & 4.6 & 5.2 \\
\hline Available $\mathrm{N}\left(\mathrm{kg} \mathrm{ha}^{-1}\right)$ & 202 & 259 & 150 & 167 & 174 & 166 & 157 & 152 & 155 & 108 \\
\hline Available $\mathrm{P}_{2} \mathrm{O}_{5}\left(\mathrm{~kg} \mathrm{ha}^{-1}\right)$ & 55.6 & 46.2 & 43.5 & 65.8 & 54.0 & 72.5 & 39.6 & 33.5 & 43.5 & 37.7 \\
\hline Available $\mathrm{K}_{2} \mathrm{O}\left(\mathrm{kg} \mathrm{ha}^{-1}\right)$ & 489 & 295 & 222 & 594 & 403 & 433 & 267 & 233 & 210 & 185 \\
\hline Available $\mathrm{S}\left(\mathrm{mg} \mathrm{kg}^{-1}\right)$ & 28 & 15 & 21 & 16 & 12 & 13 & 20 & 16 & 17 & 12 \\
\hline Ex. $\mathrm{Ca}$ and $\mathrm{Mg}\left(\mathrm{cmol}(\mathrm{p}+) \mathrm{kg}^{-1}\right)$ & 25.0 & 26.1 & 28.0 & 27.0 & 22.8 & 22.7 & 21.1 & 27.8 & 26.0 & 22.0 \\
\hline Available B ( $\left.\mathrm{mg} \mathrm{kg}^{-1}\right)$ & 2.05 & 1.58 & 1.70 & 1.67 & 1.61 & 1.43 & 2.72 & 2.33 & 2.45 & 1.61 \\
\hline DTPA extr $\mathrm{Zn}\left(\mathrm{mg} \mathrm{Kg}^{-1}\right)$ & 2.84 & 2.76 & 4.33 & 2.22 & 2.41 & 1.95 & 2.10 & 2.46 & 2.16 & 2.40 \\
\hline DTPA extr $\mathrm{Fe}\left(\mathrm{mg} \mathrm{Kg}^{-1}\right)$ & 10.8 & 11.9 & 12.7 & 16.1 & 12.9 & 11.0 & 9.63 & 11.1 & 8.92 & 9.05 \\
\hline DTPA extr $\mathrm{Mn}\left(\mathrm{mg} \mathrm{Kg}^{-1}\right)$ & 31.7 & 23.7 & 25.4 & 19.5 & 20.8 & 12.7 & 8.21 & 6.76 & 8.31 & 6.55 \\
\hline DTPA extr $\mathrm{Cu}\left(\mathrm{mg} \mathrm{Kg}^{-1}\right)$ & 4.11 & 2.73 & 6.43 & 3.26 & 4.06 & 2.80 & 2.34 & 2.25 & 2.37 & 2.18 \\
\hline CEC $\left(\mathrm{cmol}(\mathrm{p}+) \mathrm{kg}^{-1}\right)$ & 26.2 & 27.3 & 29.1 & 29.0 & 24.2 & 24.4 & 21.9 & 28.5 & 26.5 & 23.0 \\
\hline
\end{tabular}

Table 4 DTPA extractable heavy metal content in surface soils

\begin{tabular}{llll}
\hline Heavy metal & $\begin{array}{l}\text { Gabbur } \\
\left(\mathrm{mg} \mathrm{Kg}^{-1}\right)\end{array}$ & Mavanur & Katnur \\
\hline Arsenic & 0.06 & 0.09 & 0.03 \\
Cadmium & 0.02 & 0.04 & 0.02 \\
Cobalt & 0.09 & 0.17 & 0.08 \\
Chromium & 0.01 & 0.01 & 0.01 \\
Mercury & $\mathrm{Nd}$ & $\mathrm{Nd}$ & $\mathrm{Nd}$ \\
Nickel & 0.42 & 0.84 & 0.49 \\
Lead & 1.29 & 1.11 & 1.68 \\
\hline
\end{tabular}

$N d$ not detected

There was a distinct increase in DTPA extractable Mn in both Gabbur and Mavanur soils compared to Katnur and the unirrigated check close to it (Table 3). The level per se is of no concern to be toxic to plants. There was no distinct difference between the check and the three sites with respect to $\mathrm{Zn}, \mathrm{Fe}, \mathrm{Cu}$ and $\mathrm{B}$. There was no trend observed for all these micronutrients with distance from stream course.

\section{Heavy Metals Concentration}

To make an assessment of the active forms of the heavy metals, the soil samples were extracted using diethylene triamine pentaacetic acid (DTPA) and the data on heavy metals so extracted are presented in Table 4 . Hg was not detected and the content of all other heavy metals was very low. The DTPA extractable $\mathrm{Cd}$ and $\mathrm{Pb}$ values were similar to those reported by [17] but those of $\mathrm{Cr}$ and $\mathrm{Ni}$ were much less in these soils compared to the alluvial soils suggesting that much of these differences are attributed to the source of water, its interaction with soil, and agro-climatic conditions. Though the heavy metals in sewage water were not detected, they were detected in soils suggesting their gradual accumulation due to longterm application as observed also by [1].

\section{Microbial Load in Soils}

Across the sampling sites, the microbial count in sewage irrigated soils was higher for bacteria, fungi and actinomycetes, and they were about 94, 80 and 60 per cent higher

Table 5 Microbial count in rhizosphere soils in three sites

\begin{tabular}{|c|c|c|c|c|c|c|c|c|}
\hline \multirow[t]{2}{*}{ Village } & \multicolumn{2}{|c|}{ Bacteria $10^{6} \mathrm{CFU} \times \mathrm{g}^{-1}$ soil } & \multicolumn{2}{|c|}{ Fungi $10^{6} \mathrm{CFU} \times \mathrm{g}^{-1}$ soil } & \multicolumn{2}{|c|}{ Actinomycetes $10^{6} \mathrm{CFU} \times \mathrm{g}^{-1}$ soil } & \multicolumn{2}{|c|}{ E. coli $10^{3} \mathrm{CFU} \times \mathrm{g}^{-1}$ soil } \\
\hline & SI & NSI & SI & NSI & SI & NSI & SI & NSI \\
\hline Gabbur & 32 & 15 & 9 & 5 & 5 & 3 & 2 & 0 \\
\hline Mavanur & 33 & 16 & 8 & 4 & 5 & 3 & 1 & 0 \\
\hline Katnur & 28 & 18 & 9 & 5 & 5 & 4 & 2 & 0 \\
\hline
\end{tabular}

SI sewage irrigated, NIS not irrigated with sewage 
as compared to that of sewage unirrigated soils (Table 5). Similar observations were made by $[6,11]$. This can be ascribed to the addition of suspended organic materials to the soil through sewage which serves as a source of energy for microbial population. The active organic matter added by sewage water might have led to the proliferation of bacteria and fungi with somewhat lesser actinomycetes population as bacteria and fungi are known to suppress the growth of actinomycetes. The coliform bacterium (E. coli) was enumerated in sewage irrigated soils and recorded 1-2 CFU $\times 10^{3} \mathrm{~g}^{-1}$ of soil. This bacterium could enter into food chain and be hazardous to human and animal health.

\section{Conclusions}

The results from three sites under sewage water irrigation for over four decades in peri-urban Hubli city showed that there is an improvement in bulk density and aggregate stability, organic matter and available $\mathrm{N}, \mathrm{K}$ and $\mathrm{S}$ and especially $\mathrm{P}$. The heavy metals content in soils was well below the prescribed limits for phytotoxicity and the microbial population of especially bacteria and fungi improved. However, the coliform bacterium (E. coli) was observed in soils receiving long-term sewage irrigation which is a matter of concern for human health.

There was a decreasing trend of organic carbon, N, P, K and $\mathrm{S}$ with distance away from stream course and no trend was observed in respect of $\mathrm{Ca}, \mathrm{Mg}$ and $\mathrm{B}$.

Acknowledgments This work was done as a part of an on-going project on Integrating bio-treated wastewater reuse with enhanced water use efficiency to support the green economy in EU and India (Water4Crops) funded by Department of Biotechnology, New Delhi in a consortium approach. We acknowledge the financial support of DBT in conducting this work.

\section{References}

1. Adhikari S, Mitra A, Gupta SK, Banarjee SK (1994) Possibilities of using Calcutta sewage effluent and sludges for irrigation and manurial purposes. Part I physico-chemical characteristics and impact of heavy metal contents on soil and water. Proc Indian Natl Sci Acad Part B 60(6):541-552
2. Aneja KR (2003) Experiments in microbiology, plant pathology and biotechnology. New Age International Publishers, New Delhi, pp 69-71

3. Chen M, Ma LA (2001) Comparison of aquaregia methods for twenty Florida soils. Soil Sci Soc America J 65:491-499

4. CPCB (Central Pollution Control Board) (2009) Status of water supply, wastewater generation and treatment in Class I cities and Class II towns of India. Series: CUPS/70/2009-10. Central Pollution Control Board, Ministry of Environment and Forests, Government of India

5. Datta SP, Biswas DR, Saharan N, Ghosh SK, Rattan RK (2000) Effect of long-term application of sewage effluents on organic carbon, bioavailable phosphorus, potassium and heavy metal status of soils and content of heavy metals in crops grown thereon. J Indian Soc Soil Sci 48(4):836-839

6. Deshmukh SK, Singh AK, Datta SP, Annapurna K (2011) Impact of long-term wastewater application on microbiological properties of vadose zone. Environ Monit Assess 175:601-612

7. Hamid KS, Mustafa MA (1975) Dispersion as an index of relative hydraulic conductivity in salt affected soils of Sudan. Geoderma 14:107-114

8. Hundal KS, Sandhu SS (1990) Effect of sewage water on soil properties and heavy metal accumulation. Indian J Ecol 17:42-47

9. Jackson ML (1967) Soil chemical analysis. Prentice Hall of India Private Ltd, New Delhi

10. Kemper WD (1965) Aggregate stability. In: Black CA (ed) Methods of soil analysis part I agronomy monograph, vol 9. American Society Agronomy Inc., Madison

11. Kharche VK, Desai VN, Pharande AL (2011) Effect of sewage irrigation on soil properties, essential nutrient and pollutant element status of soils and plants in a vegetable growing area around Ahmednagar city in Maharashtra. J Indian Soc Soil Sci 59: 177-184

12. Malla R, Totawat KL (2006) Effect of municipal sewage on soil properties and chemical build up of vegetable crops grown on Haplustepts of sub-humid southern plains of Rajasthan. J Indian Soc Soil Sci 54:226-231

13. Minhas PS, Gupta RK (1992) Quality of irrigation waterassessment and management. ICAR, New Delhi, p 123

14. Narain V, Khan SAM, Sada R, Singh S, Prakash A (2013) Urbanization, peri-urban water (in)security and human wellbeing: a perspective from four south Asian cities. Water Int 38:930-940

15. Rattan RK, Datta SP, Singh AK, Chonkar PK, Suribabu K (2001) Effect of long term application of sewage effluents on available nutrient and available water status in soils under Keshopur effluent irrigation scheme in Delhi. J Water Manag 9:21-26

16. Renukaprasanna M, Channal HT, Sarangamath PA (2002) Characterisation of city sewage and its impact on soils and water bodies. In: Proceedings of 17 th International Conference WCSS August 14-21, Thailand

17. Yadav RK, Goal B, Sharma RK, Dubey SK, Minhas PS (2002) Post-irrigation impact of domestic sewage effluent on composition of soils, crops and ground water- A case study. Environ Int $28: 481-486$ 